\title{
Stan i kierunki zmian na rynku usług edukacyjnych. Przykład szkół wyższych regionu łódzkiego
}

\section{Wstęp}

Kapitał ludzki jest pochodną procesu ,uczenia się”, zdobywania wiedzy i umiejętności zarówno w drodze formalnego kształcenia, jak i pracy zawodowej. Wiedza, umiejętności i kompetencje społeczne interpretowane są jako wiodący zasób współczesnych gospodarek. Instytucje edukacyjne, w tym szkoły wyższe, mają zatem istotny wpływ na rozwój kapitału ludzkiego.

Szkoły wyższe stanowią część systemu nauki polskiej i systemu edukacji narodowej, a ich zwieńczeniem jest otrzymanie dyplomu, potwierdzającego ukończenie studiów wyższych i uzyskanie wyższego wykształcenia ${ }^{1}$. Stanowią one z jednej strony istotne ogniwo systemu edukacji, które kończy proces kształcenia formalnego, a $\mathrm{z}$ drugiej strony systemu społeczno-gospodarczego, stanowi punkt wyjścia do dalszego rozwoju w toku pracy zawodowej. Szkoły wyższe stanowią ważny łącznik systemu edukacji z rynkiem pracy oraz umożliwiają permanentną aktualizację specjalistycznej wiedzy i umiejętności poprzez kształcenie ustawiczne.

Związek szkół wyższych i rynku pracy jest niezaprzeczalny, przy czym obarczony jest ryzykiem konfliktu pomiędzy dynamiczną gospodarką, a inercyjnym systemem edukacyjnym ${ }^{2}$. Reforma szkolnictwa wyższego zmierza do ograniczenia tego konfliktu oraz budowania silnej pozycji szkół wyższych, w kontekście stymulowania nowoczesnej i innowacyjnej gospodarki. Potencjał intelektualny ośrodków akademickich może inspirować do rozwoju różnych form aktywności gospodarczej i społecznej, stając się nie tylko nośnikami wiedzy, ale i źródłem pozytywnych zmian.

\footnotetext{
* Adiunkt, Katedra Gospodarki Regionalnej i Środowiska, Wydział Ekonomiczno-Socjologiczny, Uniwersytet Łódzki. E-mail: agnieszka_rzenca@uni.lodz.pl

${ }^{1}$ Nauka i technika 2011, Główny Ürząd Statystyczny, s.13.

${ }^{2}$ Edukacja dla pracy. Raport o Rozwoju Społecznym Polska 2007, Program Narodów Zjednoczonych ds. Rozwoju, Warszawa 2007, s. 25.
} 
Reforma szkolnictwa wyższego jest również pochodną dokumentów strategicznych na poziomie Unii Europejskiej, które determinuja procesy modernizacyjne europejskiego szkolnictwa. Ich głównym celem jest działanie na rzecz rozwoju Europejskiego Obszaru Szkolnictwa Wyższego Unii Europejskiej oraz budowania „Europy wiedzy” poprzez:

- eliminację barier rozwoju szkolnictwa wyższego w Europie oraz zapewnienie uniwersytetom realnej autonomii;

- kształcenie w zakresie wiedzy, umiejętności i kompetencji społecznych przydatnych na rynku pracy;

- stymulowanie do nawiązywania i tworzenia sieci powiązań na zasadzie partnerstwa między biznesem oraz otoczeniem instytucjonalnym, a szkołami wyższymi w zakresie edukacji i badań;

- zmianę systemu finansowania w sektorach badań i edukacji;

- wzmocnienie zarówno interdyscyplinarności, jak i wysokiej specjalizacji kształcenia,

- poprawę wizerunku i promocję europejskiego obszaru szkolnictwa wyższego i europejskiego obszaru badawczego na świecie ${ }^{3}$.

W kontekście zmian w szkolnictwie wyższym, warunkowanych czynnikami zewnętrznymi, jak i wewnętrznymi, niemal wszystkie szkoły wyższe w kraju reorganizują swoją działalność, aktualizują bądź opracowują strategię rozwoju, określają ramy działalności naukowej oraz edukacyjnej.

Głównym celem badań realizowanych w ramach projektu „Polityka i narzędzia kreowania kapitalu ludzkiego $w$ regionie" ${ }^{4}$ była identyfikacja zmian w zakresie polityki edukacyjnej szkół wyższych w regionie łódzkim, poprzez określenie stanu i tendencji zmian oferty edukacyjnej oraz zasięgu ich ekspansji. Równie ważnym celem było wskazanie wyzwań i barier, które determinują politykę edukacyjną szkół wyższych. Dla realizacji założonego celu przeprowadzono badania:

- ankietowe, wśród ,rodzimych” szkół wyższych zlokalizowanych na terenie województwa łódzkiego;

- ilościowe, w oparciu o dane pozyskane z zasobów Urzędu Statystycznego w Łodzi oraz Głównego Urzędu Statystycznego;

- opisowe, w oparciu o dane i materiały źródłowe pochodzące z Ministerstwa Nauki i Szkolnictwa Wyższego, Narodowego Centrum Badań i Rozwoju, Narodowego Centrum Nauki oraz stron internetowych szkół wyższych.

${ }^{3}$ Szerzej A. Rzeńca, System szkolnictwa wyższego w Polsce w obliczu wyzwań gospodarki opartej na wiedzy [w:] Z. Przygodzki, Regionalny wymiar polityki rozwoju kapitalu ludzkiego. Przykład Włoch, Wielkiej Brytanii, Niemiec i Polski, Wydawnictwo Difin, Warszawa 2013.

${ }^{4}$ Projekt badań NCN nr N N114 183938, kierownik projektu dr Z. Przygodzki. 
Najwięcej trudności autorka napotkała przy realizacji badań ankietowych. Przygotowany kwestionariusz ankiety został rozesłany do 29 uczelni regionu łódzkiego, zaledwie 8 uczelni (4 publiczne oraz 4 niepubliczne) odpowiedziało pozytywnie i wyraziło chęć udziału w zaproponowanym badaniu. Większość uczelni odmówiło udziału $\mathrm{w}$ badaniach nie podając przyczyny. W przypadku dwóch uczelni udzielono odpowiedzi negatywnej, ale konkretnie ją uzasadniono: „(...) Rynek prywatnych szkót wyższych to rynek niezwykle szybko się kurczqcy $i$ Uczelnie skazane sq na funkcjonowanie w realiach poważnej konkurencji. Odpowiedzi na pytania o elementy funkcjonowania Uczelni oraz jej polityki edukacyjnej moga poważnie ostabić konkurencyjność oferty $w$ najbliższych latach (...)" oraz ,.(..) w aktualnej sytuacji uczelni niepublicznych nie widze możliwości odpowiedzi na zadane pytania (...)”. Podane argumenty wyraźnie obrazują, w jakiej trudnej sytuacji, również ze względu na niż demograficzny, znajduje się obecnie większość szkół wyższych funkcjonujących na dynamicznym rynku usług edukacyjnych. W 2000 r. w województwie łódzkim funkcjonowało 19 uczelni, w których kształciło się 99712 studentów, w 2012 roku w 29 uczelniach kształciło się 107227 studentów, przy czym nieco ponad połowa na studiach stacjonarnych. Przytoczone wypowiedzi przedstawicieli uczelni niepublicznych oraz przywołane dane statystyczne potwierdzaja, jak diametralnie zmieniła się sytuacja szkół wyższych i warunki, w jakich przyszło im funkcjonować, tym samym uzasadniają celowość podjęcia badań na ten temat.

\section{Polityka edukacyjna szkół wyższych regionu łódzkiego}

Procesy zmian są nieuniknione i powodują, że model funkcjonowania szkoły wyższej, oparty na edukacji, czy edukacji i badaniach zostaje systematycznie rozbudowany o nowe funkcje, będące pochodną zmian zachodzących w jego otoczeniu. Szkoły wyższe mają możliwość dowolnego kształtowania swojej polityki rekrutacji - wyboru pomiędzy uczelnią masową, a elitarną. Do niedawna, w Polsce, o rozdziale środków finansowych decydowała liczba przyjętych studentów, wobec czego niemal każdy absolwent szkoły ponadgimnazjalnej był przyjmowany na studia. Obecnie, ograniczenie środków finansowych oraz rosnąca konkurencja pomiędzy uczelniami, wymusza określenie preferencji w zakresie aktywności edukacyjnej oraz badawczej. Od polityki uczelni zależy, które będą pełnić rolę jedynie lokalnych ośrodków edukacyjnych i „stacji przesiadkowych" dla ambitnych studentów i naukowców", a które będą istotnym ogniwem budowania potencjału badawczego oraz gospodarki ${ }^{5}$.

${ }^{5}$ J.G. Wissema, Technostarterzy, dlaczego i jak?, Warszawa 2005, s.42, http://www.parp.gov.pl/ files/ 74/81/ 105/technostarterzy.pdf, (Dostęp: 10.10.2012). 
Na przestrzeni ostatnich 15 lat, struktura oraz liczebność szkół wyższych regionu łódzkiego uległa zasadniczej zmianie. Przełomowym momentem był rok 1997 i wprowadzone wówczas zmiany prawne, umożliwiające tworzenie uczelni zawodowych. Lawinowo zaczęły wówczas powstawać niepubliczne szkoły wyższe, które dynamicznie rozwijały swoją działalność. W 1999 r. funkcjonowało w regionie 6 uczelni publicznych i 13 niepublicznych. Zaledwie 10 lat, później w roku akademickim 2009/2010, na rynku edukacyjnym województwa łódzkiego działało 7 uczelni publicznych i 24 niepubliczne. Uczelnie te powstawały nie tylko $\mathrm{w}$ stolicy regionu, ale również $\mathrm{w}$ miastach $\mathrm{w}$ których nie było tradycji akademickich np. Sieradzu czy Pabianicach. Obecnie, w regionie łódzkim, działalność edukacyjną realizuje 7 uczelni publicznych oraz 22 niepubliczne. W ostatnich latach działalność zakończyły dwie uczelnie niepubliczne, a w ostatnim roku - 2013 r., kolejna (najpierw została ona przejęta przez uczelnię warszawską, a dziś nie prowadzi działalności).

Zdecydowanym potentatem na rynku usług edukacyjnych jest Uniwersytet Łódzki, który kształcił w 2012 r. 38\% ogółu studiujących w szkołach wyższych regionu i oferował największy wachlarz możliwości wyboru kierunków kształcenia (tabela 1). W roku 2011/2012, wśród największych szkół wyższych w Polsce, według liczby studentów, Uniwersytet Łódzki znalazł się na 4 miejscu ( $2,4 \%$ ogółu studiujących w Polsce - ponad 40 tys. studiujących łącznie z cudzoziemcami), tuż za Uniwersytetem Warszawskim, Uniwersytetem Jagiellońskim i Uniwersytetem im. A. Mickiewicza w Poznaniu.

Do roku 2010 obserwowany był ciągły wzrost liczby studentów na Uniwersytecie. W ostatnich dwóch latach zauważalny jest spadek. O ile w 2011r. liczba studentów zmalała o ok. 500 osób, o tyle w roku 2012, spadek ten był 4 razy większy i w porównaniu do 2010 r. wyniósł 5\%. Nieco inaczej przedstawia się sytuacja Politechniki Łódzkiej, której liczba studentów podlega stałej fluktuacji, niemniej jednak oscyluje wokół poziomu 20 tys. studentów. W roku 2011/2012 Politechnika Łódzka pod względem liczby studentów została sklasyfikowana na 21 pozycji, wśród polskich uczelni ( $1,14 \%$ ogółu studiujących) oraz na 7 pozycji wśród uczelni technicznych. W przypadku uczelni o długoletniej tradycji oraz renomie, sytuacja wydaje się być stabilna, aczkolwiek spadek liczby studentów na Uniwersytecie, jest niekorzystnym symptomem niżu demograficznego, odczuwanym przez coraz większą liczbę uczelni publicznych w Polsce.

Szczególnie narażone na niekorzystną sytuację demograficzną są szkoły niepubliczne. Uczelnie, które powstawały jako pierwsze w regionie i były pionierami na „nowym”, wolnym rynku usług edukacyjnych, obecnie już nie funkcjonują (np. Wyższa Szkoła Administracji Publicznej, Wyższa Szkoła Marketingu i Biznesu), wiele $z$ nich zmieniło nazwę oraz zakres swojej aktywności edukacyjnej. Przeprowadzone badania pozwalają wnioskować, iż większość niepublicznych szkół wyższych regionu, przechodziło przez trzy fazy rozwoju: roz- 
kwitu działalności, następnie eksplozji, po fazę schyłku, czy osłabienia działalności.

W Wyższej Szkole Humanistyczno-Ekonomicznej (Akademia Humanistyczno-Ekonomiczna) w 2007 r. studiowało 35442 studentów, więcej niż na publicznej uczelni technicznej - Politechnice Łódzkiej. W 2010 r. liczba studentów zmalała trzykrotnie osiagnęła poziom 10877 studiujących, by w roku 2012 mieć 4878 studentów, czyli liczę mniejszą niż w 1999 r. W przypadku tej uczelni, decydujący wpływ miały przede wszystkim decyzje Państwowej Komisji Akredytacyjnej i masowa migracja studentów do innych uczelni w regionie. Kolejna uczelnia niepubliczna o bogatej tradycji - Wyższa Szkoła Kupiecka, jeszcze w 2007 r. kształciła ponad 3 tys. studentów, w krótkim okresie czasu, ze względu na niedobór studentów znacznie ograniczyła działalność. Wśród uczelni będących w podobnej sytuacji, systematycznie „tracących” studentów, należy wymienić m.in. Salezjańską Wyższą Szkołę Ekonomii i Zarządzania w Łodzi, Wyższą Szkołę Ekonomiczno-Humanistyczną im. S. A. Pieniążka w Skierniewicach, Wyższą Szkołę Handlową im. Króla Stefana Batorego w Piotrkowie Trybunalskim, Wyższą Szkołę Humanistyczno-Ekonomiczną w Pabianicach. Problem deficytu studentów dotyka uczelni zlokalizowanych zarówno w stolicy regionu, jak i w głównych miastach subregionów.

Inaczej przedstawia się sytuacja Społecznej Wyższej Szkoły Przedsiębiorczości i Zarządzania (Społeczna Akademia Nauk), która w 1999 r. kształciła 3524 studentów i w ciągu 10 lat pięciokrotnie zwiększyła ich liczebność (2009 r. 18684 studentów). Od roku 2009 również w przypadku tej uczelni obserwujemy spadek liczby słuchaczy, niemniej jednak nie jest on tak drastyczny, jak w przypadku innych szkół wyższych.

Proces, który dziś zachodzi w Polsce, a który dotyka przede wszystkim uczelni niepublicznych, w krajach europejskich miał miejsce znacznie wcześniej. W Polsce w 2007 r. w uczelniach niepublicznych ${ }^{6}$ studiowało 34\% ogółu studentów, gdy w innych krajach europejskich wskaźnik ten był zdecydowanie niższy np. w Portugalii wyniósł $20 \%$, Francji $14 \%$, a w Hiszpanii $11 \%{ }^{7}$. W województwie łódzkim, w 2012 r. wyniósł 31,8\% ogółu studentów. Oznacza to, że w najbliższym czasie zarówno w Polsce, jak i w regionie może dojść do znacznego ograniczenia działalności uczelni niepublicznych. Na podstawie danych z 2012 r. można wyraźnie wskazać szkoły wyższe, których liczba kształcących się na studiach I, jak i II stopnia ulega ograniczeniu.

\footnotetext{
${ }^{6}$ Według klasyfikacji OECD uczelnie niepubliczne należy zaliczyć do niezależnych instytucji prywatnych.

${ }^{7}$ OECD (2008b) Higher Education to 2030, Vol 1, Demography, Vol 2, Globalisation [za:] Diagnoza stanu szkolnictwa wyższego w Polsce, Raport cząstkowy przygotowany przez konsorcjum Ernest\&Young Business Advisory oraz Instytut Badań nad Gospodarką Rynkową, listopad 2012, s. 6.
} 

Stan i kierunki zmian na rynku usług edukacyjnych...

Tabela 1. Liczba studentów (bez cudzoziemców) i kierunków studiów*

\begin{tabular}{|c|c|c|c|c|c|c|}
\hline \multirow[b]{2}{*}{ Nazwa uczelni } & \multicolumn{2}{|c|}{$1999^{\mathrm{abc}}$} & \multicolumn{2}{|c|}{2012} & \multicolumn{2}{|c|}{ 1999-2012 } \\
\hline & $\begin{array}{l}\text { Liczba } \\
\text { studen- } \\
\text { tów }\end{array}$ & $\begin{array}{l}\text { Liczba } \\
\text { kierun- } \\
\text { ków }\end{array}$ & $\begin{array}{l}\text { Liczba } \\
\text { studen- } \\
\text { tów }\end{array}$ & $\begin{array}{l}\text { Liczba } \\
\text { kierun- } \\
\text { ków }\end{array}$ & $\begin{array}{l}\text { Liczba } \\
\text { studen- } \\
\text { tów }\end{array}$ & $\begin{array}{l}\text { Liczba } \\
\text { kierun- } \\
\text { ków }\end{array}$ \\
\hline 1 & 2 & 3 & 4 & 5 & 6 & 7 \\
\hline Uniwersytet Łódzki & 32143 & 26 & 40588 & 61 & +8445 & +35 \\
\hline Politechnika Łódzka & 20327 & 23 & 20381 & 37 & +54 & +14 \\
\hline $\begin{array}{l}\text { Uniwersytet Medyczny (Akademia } \\
\text { Medyczna) }\end{array}$ & 3028 & 7 & 8159 & 14 & +5131 & +7 \\
\hline $\begin{array}{l}\text { Akademia Muzyczna im. G i K. } \\
\text { Bacewiczów w Łodzi }\end{array}$ & 582 & 5 & 617 & 5 & +35 & $\mathrm{bz}$ \\
\hline $\begin{array}{l}\text { Akademia Sztuk Pięknych } \\
\text { im. W. Strzemińskiego w Łodzi }\end{array}$ & 1054 & 6 & 1128 & 6 & +74 & $\mathrm{bz}$ \\
\hline $\begin{array}{l}\text { Państwowa Wyższa Szkoła Telewi- } \\
\text { zyjna, Teatralna i Filmowa } \\
\text { im. L. Schillera w Łodzi }\end{array}$ & 769 & 4 & 903 & 4 & +134 & $\mathrm{bz}$ \\
\hline Wyższa Szkoła Marketingu i Biznesu & 1830 & 2 & - & - & - & - \\
\hline $\begin{array}{l}\text { Akademia Humanistyczno- } \\
\text {-Ekonomiczna w Łodzi (Wyższa } \\
\text { Szkoła Humanistyczno-Ekonomiczna) }\end{array}$ & 7283 & 5 & 4878 & 16 & -2405 & +11 \\
\hline $\begin{array}{l}\text { Społeczna Akademia Nauk w Łodzi } \\
\text { (Społeczna Wyższa Szkoła Przedsiębior- } \\
\text { czości i Zarządzania) }\end{array}$ & 3524 & 1 & 16185 & 21 & +12661 & +20 \\
\hline $\begin{array}{l}\text { Wyższa Szkoła Administracji } \\
\text { Publicznej w Łodzi }\end{array}$ & 511 & 1 & - & - & - & - \\
\hline $\begin{array}{l}\text { Salezjańska Wyższa Szkoła Ekonomii } \\
\text { i Zarządzania }\end{array}$ & 534 & 2 & 51 & 3 & -483 & +1 \\
\hline $\begin{array}{l}\text { Wyższa Szkoła Informatyki i Umie- } \\
\text { jętności w Łodzi (Wyższa Szkoła } \\
\text { Informatyki) }\end{array}$ & 1981 & 2 & 3639 & 13 & +1658 & +11 \\
\hline $\begin{array}{l}\text { Wyższa Szkoła Finansów i Informaty- } \\
\text { ki im. J. Chechlińskiego w Łodzi } \\
\text { (Wyższa Szkoła Finansów, Bankowo- } \\
\text { ści i Ubezpieczeń) }\end{array}$ & 886 & 1 & 364 & 3 & -522 & +2 \\
\hline $\begin{array}{l}\text { Wyższa Szkoła Studiów Międzynaro- } \\
\text { dowych w Łodzi }\end{array}$ & 587 & 1 & 755 & 8 & +168 & +7 \\
\hline $\begin{array}{l}\text { Wyższa Szkoła Sztuki i Projektowania } \\
\text { w Łodzi }\end{array}$ & 100 & 3 & 545 & 4 & +445 & +1 \\
\hline $\begin{array}{l}\text { Wyższa Szkoła Gospodarki Krajowej } \\
\text { w Kutnie }\end{array}$ & 384 & 3 & 1191 & 8 & +807 & +5 \\
\hline $\begin{array}{l}\text { Mazowiecka Wyższa Szkoła Humani- } \\
\text { styczno-Pedagogiczna w Łowiczu }\end{array}$ & 4708 & 4 & 494 & 5 & -4214 & +1 \\
\hline
\end{tabular}


Tabela 1.

\begin{tabular}{|l|r|r|r|r|r|c|}
\hline \multicolumn{1}{|c|}{1} & \multicolumn{1}{|c|}{2} & \multicolumn{1}{c|}{4} & 5 & 6 & 7 \\
\hline $\begin{array}{l}\text { Wyższa Szkoła Ekonomiczno- Huma- } \\
\text { nistyczna im. S.A. Pieniążka w Skier- } \\
\text { niewicach }\end{array}$ & 2688 & 5 & 751 & 4 & -1937 & -1 \\
\hline $\begin{array}{l}\text { Wyższa Szkoła Kupiecka w Łodzi } \\
\text { (Wyższa Szkoła Kupiecka w Zgierzu) }\end{array}$ & 3536 & 1 & 406 & 3 & -3130 & +2 \\
\hline $\begin{array}{l}\text { Państwowa Wyższa Szkoła Zawodo- } \\
\text { wa w Skierniewicach }\end{array}$ & $923^{\mathrm{a}}$ & 4 & 1256 & 9 & +333 & +5 \\
\hline $\begin{array}{l}\text { Wyższa Szkoła Sportowa } \\
\text { im. K. Górskiego w Łodzi }\end{array}$ & $62^{\mathrm{b}}$ & 1 & 185 & 1 & +123 & $\mathrm{bz}$ \\
\hline Wyższa Szkoła Cosinus w Łodzi & $522^{\mathrm{b}}$ & 2 & 459 & 2 & -62 & $\mathrm{bz}$ \\
\hline $\begin{array}{l}\text { Wyższa Szkoła Humanistyczno- } \\
\text { Ekonomiczna w Pabianicach }\end{array}$ & $341^{\mathrm{a}}$ & 3 & 163 & 3 & -178 & $\mathrm{bz}$ \\
\hline $\begin{array}{l}\text { Wyższa Szkoła Edukacji Zdrowotnej } \\
\text { i Nauk Społecznych w Łodzi (Wyższa } \\
\text { Szkoła Edukacji Zdrowotnej w Łodzi) }\end{array}$ & $1052^{\mathrm{a}}$ & 2 & 1052 & 3 & $\mathrm{bz}$ & +1 \\
\hline $\begin{array}{l}\text { Wyższa Szkoła Humanistyczno- } \\
\text {-Ekonomiczna w Sieradzu }\end{array}$ & $445^{\mathrm{a}}$ & 1 & 254 & 3 & -192 & +2 \\
\hline $\begin{array}{l}\text { Wyższa Szkoła Kosmetyki i Nauk } \\
\text { o Zdrowiu W Łodzi }\end{array}$ & $154^{\mathrm{c}}$ & 1 & 300 & 1 & -146 & $\mathrm{bz}$ \\
\hline Wyższa Szkoła Pedagogiczna w Łodzi & $1372^{\mathrm{a}}$ & 2 & 1007 & 5 & -365 & +3 \\
\hline $\begin{array}{l}\text { Wyższa Szkoła Handlowa im. Króla } \\
\text { Stefana Batorego w Piotrkowie Tryb. }\end{array}$ & $1447^{\mathrm{a}}$ & 2 & 792 & 3 & -665 & +1 \\
\hline $\begin{array}{l}\text { Wyższa Szkoła Zawodowa Łódzkiej } \\
\text { Korporacji w Łodzi }\end{array}$ & $76^{\mathrm{a}}$ & 1 & 45 & 1 & -31 & $\mathrm{bz}$ \\
\hline $\begin{array}{l}\text { Wschód-Zachód Szkoła Wyższa } \\
\text { im. Henryka Jóźwiaka w Łodzi }\end{array}$ & $47^{\mathrm{a}}$ & 1 & 93 & 2 & -46 & +1 \\
\hline $\begin{array}{l}\text { Wyższa Szkoła Biznesu i Nauk } \\
\text { o Zdrowiu w Łodzi }\end{array}$ & $200^{\mathrm{a}}$ & 2 & 586 & 3 & +186 & +1 \\
\hline $\begin{array}{l}\text { Wyższa Szkoła Turystyki i Hotelar- } \\
\text { stwa w Łodzi }\end{array}$ & $774^{\mathrm{a}}$ & 1 & - & - & - & - \\
\hline
\end{tabular}

* niewielkie zmiany w liczbie kierunków (+/-) mogą wynikać ze zmian organizacyjnych np. kierunek finanse i rachunkowość obecnie finanse i bankowość

${ }^{\mathrm{a}} 2007 ;{ }^{\mathrm{b}} 2008$ r., ${ }^{\mathrm{c}} 2009$

Źródło: Rocznik Statystyczny Województwa Łódzkiego, Łódź 2000; Dane Urzędu Statystycznego w Łodzi.

Charakterystyczne jest, że znaczna większość uczelni regionu łódzkiego, od momentu powołania rozszerzyła swoją działalność o nowe kierunki kształcenia. Wzrost liczby uczelni oraz wzbogacenie oferty spowodowały jednak duże rozproszenie studentów i jednostkowy spadek ich liczebności. Niż demograficzny dodatkowo pogłębił niekorzystną sytuację wielu szkół wyższych. Mimo tego 
niekorzystnego procesu, szkoły wyższe dywersyfikują swoją działalność oferując i uruchamiając kierunki często z zupełnie nowych obszarów kształcenia. Przykładami mogą tu być: Uniwersytet Medyczny, który zmienił nazwę i obecnie oferuje kształcenie na kierunku socjologia, czy Wyższa Szkoła Informatyki i Umiejętności w Łodzi, która również zmieniła nazwę i kształci m.in. na kierunku fizjoterapia. Powszechne jest, że szkoły specjalizujące się dotychczas w naukach społecznych uruchamiają kierunki inżynierskie i odwrotnie. Zmiany te zachodzą $\mathrm{w}$ poszczególnych uczelniach w różnym tempie i mają różny zasięg. Szkoły publiczne (Uniwersytet Łódzki, Politechnika Łódzka) zdecydowanie dominują w tej aktywności. Również szkoły niepubliczne, które utrzymują swoją wysoką pozycje na rynku podejmują wysiłek różnicowania oferty kształcenia.

Przeprowadzane badania ankietowe wykazały, iż czynnikiem decydującym o tworzeniu nowych kierunków studiów, za którym opowiedziały się wszystkie uczelnie uczestniczące $\mathrm{w}$ badaniu, są potrzeby rynku pracy ( 8 odpowiedzi) oraz sygnały pochodzace $\mathrm{z}$ otoczenia społeczno-gospodarczego, w tym od podmiotów ze specjalistycznych branż. Dla 6 uczelni uruchamianie kierunku studiów jest naturalną konsekwencją przyjętej polityki uczelni. W przypadku 4 uczelni, uruchamianie nowych kierunków kształcenia jest często oddolną inicjatywą wydziałów/jednostek lub pracowników. Dla 3 uczelni nie bez znaczenia jest zwiększenie jej konkurencyjności, poprzez rozszerzenie czy modyfikację oferty edukacyjnej. Jedynie 1 uczelnia wskazała, iż motywem powołania nowego kierunku jest możliwość pozyskania środków finansowych na jego realizację.

Szkoły wyższe wychodzą zatem wyraźnie naprzeciw oczekiwaniom rynku pracy i podkreślają swoja otwartość na współpracę z podmiotami z otocznia. Prowadząc autonomiczną politykę edukacyjną reagują na aktualną sytuację na rynku pracy oraz poszukują alternatywnych dróg budowania pozycji konkurencyjnej w zakresie kształcenia.

Jednym z problemów polskiej edukacji wyższej jest niskie i niewystarczające (zwłaszcza w kontekście budowania gospodarki opartej na wiedzy) zainteresowanie naukami ścisłymi i studiami technicznymi. W 2007 r. zanotowano blisko 6\% spadek zainteresowania wśród kandydatów na uczelnie, studiami na kierunkach inżynieryjno-technicznych i informatycznych. W 2007 r. w regionie łódzkim, na studiach I stopnia z tytułem inżyniera, studiowało $22,4 \%$ ogółu studentów studiów I stopnia. Znamienne jest, że w 2007 r. jedynie 37,9 \% studentów na uczelni technicznej studiowało na kierunkach inżynierskich. Przez 5 lat nastapił istotny wzrost (o 7 pkt. p.p) studiujących na kierunkach inżynierskich, na studiach I stopnia i w 2012r. wyniósł 29,1 \% ogółu studiujących na studiach I stopnia. Ostatnie lata przynoszą pozytywne zmiany w tym zakresie. Również inne uczelnie, w tym niepubliczne, rozszerzają swoją ofertę o kierunki inżynierskie i realizują je z powodzeniem. W efekcie, zwiększyła się oferta kierunków inżynierskich w szkołach wyższych regionu. Obecnie na 9 uczelniach 
studenci mogą kształcić się na kierunkach inżynierskich, takich jak m.in. informatyka, transport, mechatronika, geodezja i kartografia (tabela 2).

Tabela 2. Liczba kierunków inżynierskich i udział studentów studiujących na kierunkach inżynierskich [w \%]

\begin{tabular}{|l|c|c|c|c|c|c|}
\hline \multirow{2}{*}{ Szkoły Wyższe } & \multicolumn{2}{|c|}{2007} & \multicolumn{2}{c|}{2010} & \multicolumn{2}{c|}{2012} \\
\cline { 2 - 8 } & $\begin{array}{l}\text { Liczba } \\
\text { kierun- } \\
\text { ków }\end{array}$ & $\begin{array}{c}\text { Udział } \\
\text { studen- } \\
\text { tów }\end{array}$ & $\begin{array}{c}\text { Liczba } \\
\text { kierun- } \\
\text { ków }\end{array}$ & $\begin{array}{c}\text { Udział } \\
\text { studen- } \\
\text { tów }\end{array}$ & $\begin{array}{c}\text { Liczba } \\
\text { kierun- } \\
\text { ków }\end{array}$ & $\begin{array}{c}\text { Udział } \\
\text { studen- } \\
\text { tów }\end{array}$ \\
\hline Uniwersytet Łódzki & 0 & 0 & 2 & 8,8 & 2 & 1,1 \\
\hline Politechnika Łódzka & 26 & 37,9 & 32 & 68 & 33 & 74 \\
\hline $\begin{array}{l}\text { Wyższa Szkoła Informatyki i Umie- } \\
\text { jętności w Łodzi }\end{array}$ & 1 & 44,4 & 1 & 35 & 2 & 31,8 \\
\hline $\begin{array}{l}\text { Akademia Humanistyczno- } \\
\text { Ekonomiczna w Łodzi }\end{array}$ & 3 & 15,4 & 1 & 12,1 & 1 & 9,1 \\
\hline Społeczna Akademia Nauk w Łodzi & 1 & 9 & 2 & 8 & 3 & 9 \\
\hline $\begin{array}{l}\text { Wyższa Szkoła Ekonomiczno- } \\
\text { Humanistyczna w Skierniewicach }\end{array}$ & 1 & 27,3 & 1 & 26,3 & 1 & 29,7 \\
\hline $\begin{array}{l}\text { Wyższa Szkoła Gospodarki Krajowej } \\
\text { w Kutnie }\end{array}$ & 0 & 0 & 3 & 24,8 & 3 & 26,1 \\
\hline $\begin{array}{l}\text { Państwowa Wyższa Szkoła Zawo- } \\
\text { dowa w Skierniewicach }\end{array}$ & 1 & 13,6 & 1 & 17,4 & 2 & 18 \\
\hline $\begin{array}{l}\text { Wyższa Szkoła Zawodowa Łódzkiej } \\
\text { Korporacji Oświatowej w Łodzi }\end{array}$ & 1 & 100 & 1 & 100 & 1 & 100 \\
\hline $\begin{array}{l}\text { Wyższa Szkoła Finansów i Informa- } \\
\text { tyki im. J. Chechlińskiego w Łodzi }\end{array}$ & 1 & 4,8 & 0 & 0 & 0 & 0 \\
\hline $\begin{array}{l}\text { Wyższa Szkoła Sztuki } \\
\text { i Projektowania w Łodzi }\end{array}$ & 0 & 0 & 0 & 0 & 1 & 4,6 \\
\hline
\end{tabular}

Źródło: opracowanie własne na podstawie danych Głównego Urzędu Statystycznego.

Wzrost zainteresowania kierunkami inżynierskimi jest konsekwencją polityki edukacyjnej państwa i promowaniem kierunków technicznych, matematycznych i przyrodniczych, uznanych za strategiczne dla rozwoju polskiej gospodarki. Program kierunków zamawianych, stał się istotnym narzędziem wsparcia szkół wyższych zarówno publicznych, jak i niepublicznych. Dzięki wsparciu finansowemu uczelnie mogły rozwijać kształcenie na kierunkach inżynierskich oraz innych (matematyka, chemia, fizyka, ochrona środowiska) mających znaczenie dla „budowy gospodarki opartej na wiedzy”.

Wśród aplikujących uczelni z regionu łódzkiego znalazły się: Politechnika Łódzka, Uniwersytet Łódzki, Uniwersytet Medyczny, Akademia Sztuk Pięknych, Społeczna Akademia Nauk w Łodzi, Wyższa Szkoła Informatyki i Umiejętności w Łodzi. W efekcie, z łódzkich szkół, w 2009 r. złożono 3 wnioski, 
w 2010 - 12, w 2011 - 14, w 2012 - 14. Niestety nie wszystkie wnioski uzyskały pozytywną ocenę, jak i wsparcie finansowe (tabela 3 ).

Tabela 3. Wnioski aplikacyjne uczelni wyższych regionu łódzkiego w ramach konkursów pt. Zamawianie kształcenia na kierunkach technicznych, matematycznych i przyrodniczych

\begin{tabular}{|l|c|c|c|}
\hline \multirow{2}{*}{ Rok } & \multicolumn{3}{|c|}{ Liczba wniosków* $^{*}$} \\
\cline { 2 - 4 } & $\begin{array}{c}\text { ocenionych } \\
\text { pozytywnie }\end{array}$ & $\begin{array}{c}\text { ocenionych } \\
\text { pozytywnie } \\
\text { z regionu łódzkiego }\end{array}$ & $\begin{array}{c}\text { otrzymujących } \\
\text { dofinansowanie } \\
\text { w regionie łódzkim }\end{array}$ \\
\hline 2012 & 126 & 6 & 4 \\
\hline 2011 & 88 & 8 & 5 \\
\hline 2010 & 80 & 3 & 2 \\
\hline 2009 & 59 & 3 & 1 \\
\hline
\end{tabular}

*Liczba wniosków nie uwzględnia wniosków z procedury odwoławczej

Źródło: opracowanie własne na podstawie www.ncbr.gov.pl

Uczelnią, która najbardziej aktywnie i z największym sukcesem aplikowała o środki na rozwój kierunków zamawianych była Politechnika Łódzka, która realizuje bądź realizowała kształcenie m.in. na kierunku budownictwo, inżynieria środowiska, wzornictwo, matematyka. Inne uczelnie, które uzyskały wsparcie to: Uniwersytet Łódzki (informatyka, analityka gospodarcza oraz ochrona środowiska), Wyższa Szkoła Informatyki i Umiejętności w Łodzi (informatyka oraz mechatronika) oraz Społeczna Akademia Nauk w Łodzi (informatyka).

\section{Zasięg ekspansji szkół wyższych regionu łódzkiego}

Wraz z reformą szkolnictwa wyższego i wzrostem liczby szkół wyższych, szczególnie niepublicznych, wzrosła również liczba uczelni podejmujących wysiłek organizacji procesu dydaktycznego, poza swoją główną siedzibą. Początkowo w latach 90 proces ten przebiega bardzo spokojnie. W 2000 r. 3 uczelnie z regionu łódzkiego (Uniwersytet Łódzki, Politechnika Łódzka, Społeczna Wyższa Szkoła Przedsiębiorczości i Zarządzania (obecnie Społeczna Akademia Nauk w Łodzi) kształciły studentów w czterech filiach ${ }^{8}$, spośród których tylko jedna znajdowała się na terenie województwa (Tomaszów Mazowiecki), a trzy

\footnotetext{
${ }^{8}$ Najdłuższe tradycje w zakresie organizacji procesu kształcenia poza swoją siedziba ma Politechnika Łódzka, która kształciła studentów w swojej filii w Bielsku-Białej od lat 70 XX w.
} 
kolejne poza jego granicami (w Bielsku-Białej, w Brodnicy i Ostrowie Wielkopolskim) (tabela 3). Łącznie na terenie województwa łódzkiego działało wówczas 5 filii (w tym 4 należące do uczelni z innych województw) (tabela 4) oraz 3 punkty konsultacyjne: Uniwersytetu Łódzkiego w Bełchatowie (306 studentów), Warszawskiej Szkoły Głównej Gospodarstwa Wiejskiego w Ksawerowie (197 studentów) oraz Uniwersytetu im. Stefana Wyszyńskiego w Łodzi (555 studentów).

Tabela 4. Filie, wydziały i instytuty zamiejscowe w regionie łódzkim oraz szkół wyższych z regionu łódzkiego w Polsce w 2000 r.

\begin{tabular}{|l|c|}
\hline \multicolumn{1}{|c|}{ Filie, wydziały i instytuty zamiejscowe } & Liczba studentów \\
\hline Uniwersytet Łódzki, filia w Tomaszowie Mazowieckim & 1183 \\
\hline $\begin{array}{l}\text { Szkoła Główna Gospodarstwa Wiejskiego w Warszawie, filia w Łowi- } \\
\text { czu }\end{array}$ & 91 \\
\hline Szkoła Główna Gospodarstwa Wiejskiego w Warszawie, filia w Łodzi & 68 \\
\hline $\begin{array}{l}\text { Akademia Świętokrzyska im. Jana Kochanowskiego w Kielcach, filia } \\
\text { w Piotrkowie Trybunalskim }\end{array}$ & b.d. \\
\hline $\begin{array}{l}\text { Papieski Wydział Teologiczny w Warszawie im. Św. Jana Chrzciciela, } \\
\text { filia w Łowiczu }\end{array}$ & 69 \\
\hline Politechnika Łódzka, filia w Bielsku-Białej & 5003 \\
\hline $\begin{array}{l}\text { Społeczna Wyższa Szkoła Przedsiębiorczości i Zarządzania w Łodzi, } \\
\text { filia w Brodnicy }\end{array}$ & 227 \\
\hline $\begin{array}{l}\text { Społeczna Wyższa Szkoła Przedsiębiorczości i Zarządzania w Łodzi, } \\
\text { filia w Ostrowie Wielkopolskim }\end{array}$ & 306 \\
\hline
\end{tabular}

Źródło: opracowanie własne na podstawie danych statystycznych Urzędu Statystycznego w Łodzi.

Do 2005 r. sytuacja w województwie łódzkim w tym zakresie nie ulegała większym zmianom, bowiem funkcjonowało wówczas $\mathrm{w}$ województwie 7 ośrodków typu: filie, wydziały i instytuty zamiejscowe (głównie filie) oraz 5 ośrodków typu: zamiejscowe ośrodki dydaktyczne, punkty konsultacyjne. Znowelizowane przepisy prawa w 2005 r. wprowadziły nową organizację dotychczasowego systemu kształcenia, co umożliwiało szkołom wyższym tworzenie filii i zamiejscowych, podstawowych jednostek organizacyjnych oraz zamiejscowych ośrodków dydaktycznych na szerszą skalę?. W konsekwencji tej reorganizacji nastapił przede wszystkim lawinowy rozwój zamiejscowych ośrodków dydaktycznych.

${ }^{9}$ Do 2005 r. uczelnie wyższe mogły tworzyć filie, instytuty i wydziały zamiejscowe obecnie filie, zamiejscowe podstawowe jednostki organizacyjne oraz zamiejscowe ośrodki dydaktyczne, punkty konsultacyjne obecnie zamiejscowe ośrodki dydaktyczne. 
Uczelnie regionu łódzkiego zarówno publiczne, jak i niepubliczne, rozpoczęły ekspansję, zwiększając zasięg terytorialny oddziaływania zarówno w granicach województwa, jak i poza nim. W efekcie, w 2011 r. 4 uczelnie z regionu łódzkiego, 2 publiczne i 2 niepubliczne, prowadziły łącznie 41 zamiejscowych ośrodków dydaktycznych. Zdecydowanie mniejszą aktywnością w tym zakresie cechują się uczelnie publiczne, których zamiejscowe ośrodki dydaktyczne stanowią zaledwie $15 \%$ ogółu i zlokalizowane są przede wszystkim w regionie łódzkim. Szeroki zasięg oddziaływania charakteryzuje: Akademię HumanistycznoEkonomiczna, która prowadziła w 2011 r. 18 zamiejscowych ośrodków dydaktycznych, w tym $5 \mathrm{w}$ województwie łódzkim oraz Społeczną Akademię Nauk, która prowadziła 17 zamiejscowych ośrodków dydaktycznych w tym $5 \mathrm{w}$ województwie i jeden za granicą w Londynie (załącznik 1).

Łącznie, w regionie łódzkim, w 2011 r. 7 szkół wyższych prowadziło swoją działalność w 18 miastach $^{10}$. W przeciąu 6 lat liczba zamiejscowych ośrodków dydaktycznych (dawnych punktów konsultacyjnych) w regionie wzrosła ponad 3 razy, a w porównaniu do 2000 r. 6 razy. Większość zamiejscowych ośrodków dydaktycznych związanych jest z „łódzkimi” szkołami wyższymi. 3 uczelnie „zewnętrzne” prowadzą działalność w 4 miejscowościach. Należy zauważyć, iż wśród nich są: Szkoła Główna Gospodarstwa Wiejskiego w Warszawie, która od wielu lat prowadzi działalność edukacyjną na terenie województwa łódzkiego oraz Wyższa Szkoła Menedżerska w Warszawie, która dopiero rozpoczyna działalność na obszarze województwa.

Od 2005 r. obserwujemy również istotne zmiany w zakresie tworzenia filii i zamiejscowych podstawowych jednostek organizacyjnych przez szkoły z regionu łódzkiego. W 2011 r. 7 uczelni, głównie niepublicznych (wyjątek stanowi Uniwersytet Łódzki), prowadziło działalność w 20 miastach. Zdecydowanie przoduje Społeczna Akademia Nauk, która uruchomiła niemal 1/3 wszystkich jednostek ( 8 wydziałów zamiejscowych), następnie 4 wydziały zamiejscowe prowadzi Wyższa Szkoła Kupiecka w Lodzi, a kolejne 3 Wyższa Szkoła Informatyki i Umiejętności w Łodzi (załącznik 2).

Łącznie w 2011 r., w regionie łódzkim, studenci kształcili się w 7 ośrodkach (filiach, czy zamiejscowych, podstawowych jednostkach organizacyjnych), które prowadziły 3 uczelnie rodzime (4 jednostki) oraz 3 uczelnie z innych województw. W porównaniu do roku 2000, łączna liczba nie uległa zasadniczej zmianie, niemniej jednak zmianie uległ katalog szkół wyższych oferujących kształcenie. W zestawieniu pojawiła się m.in. Wyższa Szkoła Kupiecka w Lodzi z wydziałami zamiejscowymi w Piotrkowie Trybunalskim i Sieradzu.

${ }^{10} \mathrm{~W}$ danych statystycznych pojawia się informacja o 19 zamiejscowych ośrodkach dydaktycznych w regionie łódzkim, różnica jest związana jest zakwalifikowaniem zamiejscowego ośrodka dydaktycznego w Londynie. 
Porównując lokalizację i zasięg oddziaływania szkół wyższych regionu łódzkiego, niezależnie od formy organizacyjnej, możemy wskazać:

1) uczelnie, które rozpraszają swoją aktywność terytorialnie, w celu zwiększenia szans pozyskania słuchaczy;

2) uczelnie, które koncentrują swoją działalność w wybranych województwach, np. uczelnie publiczne działające głównie w województwie łódzkim;

3) uczelnie, które prowadzą swoją działalność w tych samych miejscowościach bądź w bezpośrednim sąsiedztwie. Powielanie lokalizacji jest powszechne szczególnie w przypadku uczelni niepublicznych, np. Akademia Humanistyczno-Ekonomiczna i Społeczna Akademia Nauk posiadają swoje jednostki niemal w tych samych miastach (Radomsko, Wielun, Piotrków Trybunalski, Bełchatów, Sieradz i Zduńska Wola), mimo iż różni się ich forma organizacyjno-prawna;

4) dysproporcje liczebności studentów w poszczególnych ośrodkach tej samej uczelni oraz pomiędzy ośrodkami o tej samej lokalizacji (zróżnicowanie pomiędzy poszczególnymi ośrodkami charakterystyczne np. w Tomaszowie Mazowieckim, Sieradzu czy Radomsku). Znamienne jest, iż w ostatnich latach uczelnie ograniczają działalność, czy też są zmuszone się z niej wycofać. Malejąca liczba studentów, konkurencja czy brak pozytywnej oceny Polskiej Komisji Akredytacji to najczęstsze przyczyny zaprzestania działalności.

\section{Wybrane przykłady dywersyfikacji oferty edukacyjnej szkół wyższych regionu łódzkiego}

W obliczu malejącej liczby studentów, a także ograniczania finansowania $\mathrm{z}$ budżetu państwa, wdrażanie rozwiązań z zakresu elastycznych form kształcenia, może być antidotum na problemy szkół wyższych oraz służyć upowszechnianiu procesu „uczenia się przez całe życie” (LLL). Elastyczny systemu kształcenia pozwala pozyskać studentów, którzy z różnych względów nie mogą skorzystać z tradycyjnej oferty kształcenia, sprzyja zróżnicowaniu struktury społeczności studenckiej, umiędzynarodowieniu studiów oraz czyni ofertę edukacyjną uczelni bogatszą i bardziej atrakcyjną ${ }^{11}$. Możliwości realizowania przez uczelnie wyższe elastycznych form kształcenia są ogromne: od szkoleń, przez kursy fakultatywne w ramach toku studiów, po studia podyplomowe.

${ }^{11}$ Benchmarking $w$ szkolnictwie wyższym. Wybrane problemy: elastyczność, e-learning, wewnętrzne systemy zapewniania jakości w systemie ksztatcenia, gospodarka zasobami dla poprawy produktywności $i$ konkurencyjności- kontrola zarzqdcza, praca zbiorowa, J. Woźnicki (red.), Fundacja Rektorów Polskich, Warszawa 2012, s. 126, http://www.frp.org.pl/publikacje/ FRPBench2012.pdf, (Dostęp: 30.08.2013). 
Dotychczas najpopularniejszą formą były studia podyplomowe, realizowane głównie przez uczelnie publiczne. Reorientacja podejścia do kształcenia i wyeksponowanie jego ciagłego charakteru, zmobilizowało szkoły wyższe do rozszerzania swojej oferty. Szczególne warunki stworzyła również dostępność środków unijnych, które pozwalają zaproponować atrakcyjną ofertę, wzbogacającą dotychczasową działalność edukacyjną (tabela 5).

Tabela 5. Elastyczne formy kształcenia w wybranych szkołach wyższych

\begin{tabular}{|c|c|}
\hline Nazwa szkoły wyższej & Charakterystyka projektu \\
\hline $\begin{array}{l}\text { Wyższa Szkoła Finansów } \\
\text { i Informatyki im. J. Chechliń- } \\
\text { skiego w Łodzi }\end{array}$ & $\begin{array}{l}\text { Projekt „Lódzka akademia wieku średniego”, którego ce- } \\
\text { lem jest zwiększenie atrakcyjności na rynku pracy } 80 \text { osób } \\
\text { bezrobotnych (w tym } 45 \text { kobiet i } 35 \text { mężczyzn), powyżej } 50 \\
\text { roku życia zamieszkujących na terenie podregionu łódzkiego. } \\
\text { W ramach projektu jest możliwość uzyskania certyfikatu ECDL } \\
\text { Core, potwierdzającego nabycie umiejętności obsługi kompute- } \\
\text { ra i podstawowych programów biurowych; } \\
\text { Projekt „Podnieś kwalifikacje - mów po angielsku”, które- } \\
\text { go głównym celem jest podniesienie poziomu kompetencji } \\
\text { kluczowych (językowych) na łódzkim rynku pracy u } 200 \text { za- } \\
\text { trudnionych osób w wieku } 25-64 \text { lata (w tym } 110 \text { kobiet i } 90 \\
\text { mężczyzn), zamieszkujących podregion tódzki i miasto Łódź }{ }^{12} \text {. }\end{array}$ \\
\hline $\begin{array}{l}\text { Wyższa Szkoła Studiów } \\
\text { Międzynarodowych w Łodzi }\end{array}$ & $\begin{array}{l}\text { Projekt „Wzmocnienie potencjału dydaktycznego uczelni } \\
\text { poprzez wprowadzenie do programu studiów nowych inno- } \\
\text { wacyjnych specjalności”. Celem projektu było poszerzanie } \\
\text { oferty kształcenia o innowacyjne specjalności (Ekologia euro- } \\
\text { pejska, Zarządzenie państwem, Informatyka internetowa, Ko- } \\
\text { munikacja interkulturowa w jęz. ang.) na studiach stacjonar- } \\
\text { nych i niestacjonarnych w formie zajęć fakultatywnych (roczny } \\
\text { kurs) }{ }^{13} \text {. } \\
\text { Projekt „Urzędnik w UE”, cykl szkoleń dedykowany pra- } \\
\text { cownikom samorządowym }{ }^{14} \text {. }\end{array}$ \\
\hline
\end{tabular}

Źródło: opracowanie własne na podstawie http://www.wirtualnaekonomia.pl/; www.wssm.lodz.pl, (Dostęp: 10.09.2013).

${ }^{12}$ Projekt współfinansowany ze środków Unii Europejskiej w ramach Europejskiego Funduszu Społecznego, w ramach Priorytetu 9 „Rozwój wykształcenia i kompetencji w regionach”, Poddziałanie 9.6.2 „Podwyższanie kompetencji osób dorosłych w zakresie ICT i znajomości języków obcych" Programu Operacyjnego Kapitał Ludzki.

${ }^{13}$ Projekt współfinansowany ze środków Unii Europejskiej w ramach Europejskiego Funduszu Społecznego realizowany w ramach działania 4.1 Instytucja wdrażająca Ministerstwo Nauki i Szkolnictwa Wyższego, projekt realizowany w latach 2009-2013.

${ }^{14}$ Projekt współfinansowany ze środków Unii Europejskiej w ramach Europejskiego Funduszu Społecznego w ramach Działania 5.2, Instytucja wdrażająca Ministerstwo Spraw Wewnętrznych i Administracji, realizowany w 2009 r., zakończony. 
Uruchomienie przez szkoły wyższe elastycznych form kształcenia stanowi odpowiedź na potrzeby rynku pracy, by zwiększyć kompetencje i możliwości zatrudnienia osób bezrobotnych, kobiet i mężczyzn po 50 roku życia, czy kobiet wracających po urlopach wychowawczych. Umożliwia również szybkie reagowanie na lokalne i regionalne problemy w zakresie edukacji oraz potrzeby sygnalizowane przez podmioty $\mathrm{z}$ otoczenia. Szeroka oferta elastycznych form kształcenia może być dedykowana również studentom, czy absolwentom, co pozwala monitorować ich kariery zawodowe oraz budować stałe relacje i kontakty.

Obok rozwijanych elastycznych form kształcenia, uczelnie wykorzystują nowoczesne technologie, aby zwiększyć dostępność, zasięg oraz wzbogacić ofertę edukacyjną. W kontekście zachodzących zmian, istotne jest, aby proces dydaktyczny był efektywny i atrakcyjny. Rozwój cyfrowych technik i technologii przekazu, stwarza takie możliwości i pozwala dotrzeć do szerszej grupy odbiorców. Wśród zalet e-learningu i proefektywnościowych walorów nauczania elektronicznego, można wskazać:

- możliwość wykreowania sytuacji indywidualnego zaangażowania osoby uczącej się w proces zdobywania wiedzy, bądź kształtowania praktycznych umiejętności;

- możliwość kształtowania przejrzystej struktury przekazywanych treści merytorycznych;

- możliwość kształtowania wielokanałowej formy przekazywanych treści merytorycznych ${ }^{15}$.

Dynamicznie rozwijające się nowe technologie teleinformatyczne, umożliwiające rozwój nauczania na odległość w wersji cyfrowej, mają jednak przeciwników, którzy wskazują że co prawda z technologii tej korzystają miliony ludzi, którzy w przeciwnym razie nie mieliby dostępu do zaawansowanej nauki, ale jako narzędzie uczenia się jest raczej słabe ${ }^{16}$.

Uczelnie wyższe podejmują jednak wyzwanie i coraz częściej korzystają z najnowszych osiagnięć technologii cyfrowych, by pozyskać studentów oraz rozszerzyć swoją działalność. Wśród uzyskanych odpowiedzi z 8 uczelni, zaledwie 2 oferują kształcenie w trybie $e$-learningu, w przypadku jednej są to studia podyplomowe w przypadku drugiej są to zarówno studia stacjonarne, jak i niestacjonarne, studia podyplomowe oraz kursy i szkolenia. Należy jednak mieć świadomość, że uczelnie nie biorące udziału w badaniach ankietowych również oferują ten model kształcenia, który stanowi uzupełnienie realizowanego procesu dydaktycznego lub też jest oparty wyłącznie o tryb e-learningu.

\footnotetext{
${ }^{15}$ P. Jurek, E - learning w świetle badań nad uczeniem się. Czy komputer jest lepszy od nauczyciela? Meritum 1-2/ 2002, str. 8 - 9.

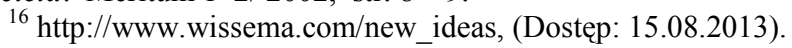


Od 2010 r. w Wyższej Szkole Finansów i Informatyki im. J. Chechlińskiego w Lodzi realizowany jest projekt „E-learning: nowoczesna i innowacyjna uczelnia", na potrzeby którego opracowano model kształcenia na platformie edukacyjnej, połączony ze spotkaniami na uczelni (tzw. kształcenie mieszane - blended learning). W ramach realizowanego projektu, uczelnia oferuje kształcenie na kierunku Ekonomia (studia I stopnia) oraz studia podyplomowe Psychologia i negocjacje w biznesie ${ }^{17}$.

\section{Edukacja i jej rola w realizacji Strategii Europa 2020}

„Gospodarka oparta na wiedzy" stała się istotą programowania w latach 2007-2013, której towarzyszyły różnorodne instrumenty finansowe (m.in. kierunki zamawiane finansowane z PO KL). O ich popularności świadczy liczba kierunków zamawianych i uczelni aplikujących o środki na innowacyjne kierunki i rozwiązania dydaktyczne. Nowy okres programowania, to z jednej strony kontynuacja Strategii Lizbońskiej i realizacji działań w zakresie stymulowana gospodarki opartej na wiedzy, z drugiej wyjście naprzeciw oczekiwaniom Strategii Europa 2020.

W 2012 r. rozpoczęto nabór wniosków w dwóch konkursach pt. „Wzmocnienie potencjału dydaktycznego uczelni w obszarach kluczowych w kontekście celów strategii Europa $2020^{\prime \prime 18}$. W ich ramach wsparcie zostało udzielone uczelniom, które przede wszystkim realizować będą kierunki studiów zgodne z obszarami kształcenia, wskazanymi jako najistotniejsze z punktu widzenia celów strategii Europa 2020.

Uczelnie zdecydowanie rywalizują o środki finansowe, na co wskazują kolejne nabory wniosków, niosących możliwość uzyskania wsparcia. W drugim naborze wniosków, w którym pula środków była znacznie mniejsza, rywalizowało więcej uczelni. Zarówno w pierwszym, jak i drugim konkursie aplikowały uczelnie z regionu łódzkiego (tabela 6).

${ }^{17} \mathrm{http}: / /$ www.wirtualnaekonomia.pl/

${ }^{18}$ W ramach Działania 4.3 Wzmocnienie potencjału dydaktycznego uczelni w obszarach kluczowych w kontekście celów Strategii Europa 2020, Priorytetu IV Programu Operacyjnego Kapitał Ludzki. 
Tabela 6. Wzmocnienie potencjału dydaktycznego uczelni w obszarach kluczowych, w kontekście celów Strategii Europa 2020

\begin{tabular}{|l|c|c|c|c|c|}
\hline \multirow{2}{*}{} & \multicolumn{5}{|c|}{ Liczba wniosków szkół wyższych } \\
\cline { 2 - 6 } & $\begin{array}{c}\text { złożonych } \\
\text { ogółem }\end{array}$ & $\begin{array}{c}\text { z regionu } \\
\text { łódzkiego }\end{array}$ & $\begin{array}{c}\text { ocenionych } \\
\text { pozytywnie }\end{array}$ & $\begin{array}{c}\text { zakwalifiko- } \\
\text { wanych } \\
\text { do dofinan- } \\
\text { sowania }\end{array}$ & $\begin{array}{c}\text { z regionu } \\
\text { łódzkiego }\end{array}$ \\
\hline Nabór 1* & 92 & 5 & 39 & 23 & 2 \\
\hline Nabór 2** & 145 & 7 & 80 & 21 & 0 \\
\hline
\end{tabular}

*1/POKL/4.3/2012 - z kwotą środków na dofinansowanie projektów w wysokości 100000000 PLN ** 2/POKL/4.3/2012 - z kwotą środków na dofinansowanie projektów w wysokości 40000000 PLN

Źródło: opracowanie własne na podstawie www.ncbr.gov.pl

W trybie postępowania, dotyczącym pierwszego konkursu pozytywnie zaopiniowano 3 wnioski, dofinansowanie uzyskały natomiast 2 uczelnie. W drugim konkursie zaledwie 1 wniosek uzyskał pozytywną opinię, jednak ze względu na brak środków nie uzyskał wsparcia (tabela 7). Mimo niepowodzeń w aplikowaniu o środki, aktywność uczelni należy ocenić wysoko. Decydują się one na wysiłek organizacyjny i przygotowanie merytoryczne autorskiego projektu dydaktycznego, wychodzącego naprzeciw oczekiwaniom gospodarki. Uczelnie określają w ten sposób swój potencjał i wskazują wiodące obszary aktywności w zakresie edukacji. Zadowalający jest fakt, iż wnioski aplikacyjne dotyczą różnych etapów (poziomów) kształcenia, od kierunków studiów, przez studia podyplomowe po studia doktoranckie. Uczelnie nie tylko modernizują dotychczasowe, programy kształcenia, ale proponują nowe, będące często wyzwaniem i innowacją dla procesu dydaktycznego.

Tabela 7. Wnioski aplikacyjne uczelni wyższych regionu łódzkiego w ramach konkursów pt. Wzmocnienie potencjału dydaktycznego uczelni w obszarach kluczowych w kontekście celów Strategii Europa 2020

\begin{tabular}{|c|c|c|}
\hline & $\begin{array}{c}\text { Ocena pozytywna (miejsce na liście } \\
\text { rankingowej) }\end{array}$ & Ocena negatywna \\
\hline 1 & 2 & 3 \\
\hline Lp.1 & $\begin{array}{l}\text { - InfoGeoLog: Informatyka, Geologia, } \\
\text { Logistyka. Kształcenie w zawodach } \\
\text { przyszłości w odpowiedzi na oczeki- } \\
\text { wania pracodawców (2); Uniwersytet } \\
\text { Łódzki } \\
\text { - Program rozwojowy Państwowej Wyż- } \\
\text { szej Szkoły Zawodowej w Skierniewi- } \\
\text { cach (19); Państwowa Wyższa Szkoła } \\
\text { Zawodowa w Skierniewicach }\end{array}$ & $\begin{array}{l}\text { - UMED3-BioSCience-Interdyscyplinarne } \\
\text { studia doktoranckie w zakresie biotech- } \\
\text { nologii medycznej w kontekście celów } \\
\text { strategii Europa } 2020 \text { w odpowiedzi na } \\
\text { potrzeby gospodarki opartej na wiedzy; } \\
\text { Uniwersytet Medyczny w Łodzi } \\
\text { - Fizjoterapia - strategia na przyszłość; } \\
\text { Wyższa Szkoła Humanistyczno- } \\
\text { Ekonomiczna w Sieradzu }\end{array}$ \\
\hline
\end{tabular}


44 Stan i kierunki zmian na rynku usług edukacyjnych...

Tabela 7 .

\begin{tabular}{|c|c|c|}
\hline 1 & 2 & 3 \\
\hline & $\begin{array}{l}\text { - Absolwent z gwarancją pracy- } \\
\text { modernizacja programów nauczania na } \\
\text { kierunkach studiów kluczowych w } \\
\text { kontekście rozwoju rynku pracy (24); } \\
\text { Wyższa Szkoła Informatyki i Umiejęt- } \\
\text { ności w Łodzi }\end{array}$ & \\
\hline Lp. 2 & $\begin{array}{l}\text { - W kierunku Europa 2020- poszerzenie } \\
\text { oferty edukacyjnej i wzrost potencjału } \\
\text { Społecznej Akademii Nauk w obszarze } \\
\text { informatyki i logistyki (38); Społeczna } \\
\text { Akademia Nauk w Łodzi }\end{array}$ & $\begin{array}{l}\text { - Klucz do sukcesu - Wyższa Szkoła } \\
\text { Informatyki i Umiejętności Łodzi } \\
\text { - Wzmocnienie potencjału dydaktycznego } \\
\text { - Politechnika Łódzka 2020; Politechni- } \\
\text { ka Łódzka } \\
\text { - Wzmocnienie potencjału dydaktycznego } \\
\text { uczelni w obszarze transportu i grafiki - } \\
\text { poprzez realizacje nowych kierunków } \\
\text { studiów podyplomowych; Akademia } \\
\text { Humanistyczno-Ekonomiczna w Łodzi } \\
\text { - Kompetentne kadry jutra- Uniwersytet } \\
\text { Łódzki dla Europa 2020; Uniwersytet } \\
\text { Łódzki } \\
\text { - Architektura wnętrz -kreowanie prze- } \\
\text { strzeni w najbliższym otoczeniu czło- } \\
\text { wieka; Akademia Sztuk Pięknych } \\
\text { w Łodzi } \\
\text { - BioMonit- Przygotowanie, otwarcie } \\
\text { i realizacja dwóch nowych kierunków } \\
\text { studiów podyplomowych oraz kursu: } \\
\text { Dobra praktyka w badaniach klinicz- } \\
\text { nych w kontekście celów Strategii } \\
\text { Europa 2020; Uniwersytet Medyczny } \\
\text { w Łodzi }\end{array}$ \\
\hline
\end{tabular}

Źródło: opracowanie własne na podstawie materiałów źródłowych www.nauka.gov.pl, (Dostęp: 03.09.2013).

W kontekście zrealizowanych badań, stwierdzenie dziś, iż uczelnie niepubliczne ,(..) koncentrują się na niskonakładowych studiach niestacjonarnych $(\ldots)^{19, " ~ n i e ~ z n a j d u j e ~ u z a s a d n i e n i a, ~ b o w i e m ~ u c z e l n i e ~ t e ~ p o p r z e z ~ w i e l o p ł a s z c z y-~}$ znowe projekty edukacyjne, budują swoją pozycję konkurencyjną oraz wyraźnie zaznaczają swoją obecność w systemie edukacji regionu.

„Trzecia misja” szkół wyższych eksponowana w literaturze, jak i dokumentach strategicznych UE, niejako wymusza kontakt uczelni z otoczeniem. Z dru-

${ }^{19}$ Diagnoza stanu szkolnictwa wyższego w Polsce, Raport cząstkowy przygotowany przez konsorcjum Ernest\&Young Business Advisory oraz Instytut Badań nad Gospodarką Rynkową, listopad 2012, s. 6. 
giej strony uczelnie same dostrzegaja potrzebę nawiązywania, rozwijania i zacieśniania kontaktów oraz współpracy z podmiotami gospodarczymi i instytucjami. Odrębną kwestią jest proces adaptacji do zmian oraz wykorzystania powiązań z gospodarką na rzecz skutecznego kształcenia, przygotowania i wyposażenia absolwentów w wiedzę i umiejętności niezbędne dla potrzeb gospodarki i społeczeństwa. Dlatego pożądane są instrumenty, które będą motywowały uczelnie do skutecznego zbliżenia swojej działalności do potrzeb otoczenia w ramach procesu dydaktycznego.

Dla podniesienia atrakcyjności programów kształcenia, poprzez wykorzystanie nowych metod dydaktycznych oraz ich współtworzenie z przedsiębiorcami, Ministerstwo Nauki i Szkolnictwa Wyższego ogłosiło konkurs na najlepsze programy studiów. Spośród 207 zgłoszonych wniosków, w konkursie nagrodzono 62 kierunki studiów, prowadzone przez 37 uczelni (w tym 9 uczelni niepublicznych) z 17 polskich miast. W gronie wyróżnionych znalazła się 1 uczelnia z regionu łódzkiego - Politechnika Łódzka (PŁ), która zdobyła nagrodę za programy kształcenia dla 3 kierunków. Politechnika Łódzka była jedną z 9 nagrodzonych uczelni technicznych ${ }^{20}$. Mimo dużej konkurencji zgłoszonych programów (maksymalna ocena wyniosła 112 pkt., a minimalna 90, programy kształcenia PŁ znalazły się w czołówce, a nagrodzone kierunki zajęły 6, 7 i 21 miejsce w rankingu (tabela 8). Na szczególna uwagę nagrodzonych programów zasługuje:

1. nauczanie praktyczne poprzez wykorzystanie nowoczesnego zaplecza sprzętowo-programistycznego, infrastruktury oraz dostęp do nowoczesnych, specjalistycznych laboratoriów $\mathrm{z}$ różnych dyscyplin nauk technicznych;

2. współpraca z zakładami produkcyjnymi i innymi z regionu łódzkiego, gdzie studenci odbywają praktyki specjalistyczne, wycieczki dydaktyczne i wyjazdy studyjne, spotkania tematyczne z ekspertami oraz realizują prace dyplomowe ${ }^{21}$.

Tabela 8. Nagrodzone programy kształcenia na Politechnice Łódzkiej

\begin{tabular}{|l|c|c|c|}
\hline \multicolumn{1}{|c|}{ Kierunek (miejsce w rankingu) } & $\begin{array}{c}\text { Poziom } \\
\text { studiów }\end{array}$ & Profil studiów & $\begin{array}{c}\text { Przyznane } \\
\text { punkty }\end{array}$ \\
\hline Automatyka i robotyka (6) & II stopień & ogólnoakademicki & 108,5 \\
\hline Inżynieria bezpieczeństwa pracy (7) & I stopień & ogólnoakademicki & 108,0 \\
\hline Chemia budowlana (21) & I stopień & ogólnoakademicki & 101,0 \\
\hline
\end{tabular}

Źródło: opracowanie własne na podstawie listy wyników na „Milion na najlepsze programy studiów":http://www.nauka.gov.pl/g2/oryginal/2013_05/a4bd077386d194ebd405d37f68ccbb7d.pdf

${ }^{20}$ Politechnika Warszawska - 4 kierunki, Akademia Górniczo-Hutnicza -4 kierunki, Politechnika Krakowska im. Tadeusza Kościuszki - 2 kierunki, Politechnika Poznańska - 2 kierunki, Politechnika Świętokrzyska w Kielcach - 2 kierunki, Politechnika Białostocka - 2 kierunki, Politechnika Gdańska - 1 kierunek, Politechnika Śląska - 1 kierunek

${ }^{21} \mathrm{http} / / /$ www.nauka.gov.pl/g2/oryginal/2013_05/900d0f241adb26b5b208358d11526287.pdf 
Nagrodzone kierunki uzyskały wsparcie finansowe na realizacje zaproponowanych programów kształcenia. $\mathrm{W}$ ramach dotacji podmiotowej $1 \mathrm{mln}$ zł ma zostać przekazany na doskonalenie oferty dydaktycznej, np. sfinansowanie nowoczesnych technik i narzędzi stosowanych podczas wykładów i ćwiczeń, pokrycie kosztów praktyk zawodowych dla studentów czy lepsze przygotowanie wykładowców akademickich ${ }^{22}$.

Innowacyjnym rozwiązaniem jest tworzenie oferty dydaktycznej, we współpracy z innymi uczelniami z regionu czy kraju. Otwarcie na współpracę, mimo często trudnych warunków rywalizacji, potrafi jednak jednoczyć i może stanowić warunek budowania specjalistycznego potencjału.

Nagrodzony program kształcenia dla kierunku chemia budowlana powstał we współpracy Politechniki Łódzkiej, Politechniki Gdańskiej i Akademii Górniczo-Hutniczej. Student tego kierunku może przez kilka semestrów studiować w dowolnej z trzech zaangażowanych w projekt szkół wyższych. Pracę dyplomową przygotowuje zaś $\mathrm{w}$ laboratorium wydziałowym lub $\mathrm{w}$ firmach powiązanych z przemysłem. Wspólne prowadzenie kierunku przez trzy uczelnie daje studentom możliwość realizacji przedmiotów niedostępnych na ich uczelni macierzystej. Uczenie partnerskie przewidują też wymianę kadry akademickiej oraz zwiększenie liczby zajęć prowadzonych przez specjalistów z przemysłu ${ }^{23}$.

Współpraca między uczelniami może dotyczyć różnorodnych form kształcenia od studiów I i II stopnia, po szkolenia, kursy, czy studia podyplomowe. Dobrym przykładem są studia podyplomowe Logopedia z emisja głosu, realizowane na Uniwersytecie Łódzkim, ale współprowadzone przez pracowników naukowych z innych uczelni. Zajęcia dydaktyczne prowadzą pracownicy Uniwersytetu Łódzkiego - Wydział Nauk o Wychowaniu, pracownicy Uniwersytetu Medycznego Łodzi, a także specjaliści z innych ośrodków akademickich w Polsce (m.in. Uniwersytet Śląski, Uniwersytet Marii Curie-Skłodowskiej w Lublinie) oraz doświadczeni logopedzi z różnych placówek oświatowych i służby zdrowia ${ }^{24}$.

\section{Bariery funkcjonowania szkoły wyższej oraz zagrożenia dla realizacji polityki edukacyjnej}

Główne bariery funkcjonowania uczelni, które stanowią zagrożenie dla polityki edukacyjnej związane są z systemem prawno-organizacyjnym oraz warunkami finansowymi. „Finanse stanowią najbardziej wrażliwe miejsce systemu

\footnotetext{
${ }^{22}$ http://www.nauka.gov.pl/aktualnosci-ministerstwo/ogloszenie-wynikow-konkursu-na-milion-nanajlepsze-programy-studiow.html

${ }^{23} \mathrm{http}: / /$ www.nauka.gov.pl/g2/oryginal/2013_05/900d0f241adb26b5b208358d11526287.pdf

${ }^{24} \mathrm{http}: / /$ www.uni.lodz.pl/studia/studium,tematyka,381, (Dostęp: 10.10.2013).
} 
organizacyjnego szkolnictwa wyższego"25, czego dowodzą przeprowadzone badania ankietowe. Wynika z nich, że wszystkie uczelnie borykają się z problemami finansowymi i poszukują nowych źródeł finansowania działalności edukacyjnej. Wyraźnie wskazują jednak na trudności w pozyskaniu środków finansowych z zewnątrz (5 odpowiedzi) oraz zbyt mały budżet uczelni (4 odpowiedzi). Kolejna grupa barier związana jest z polityką rządu wobec uczelni wyższych (4 odpowiedzi), również $\mathrm{w}$ kontekście finansowania oraz niestabilności prawa (3 odpowiedzi). Mimo uzyskanej autonomii, nadal ustawy i rozporządzenia w istotny sposób determinują zakres działalności uczelni publicznych, jak i niepublicznych. Wprowadzane zmiany instytucjonalno-organizacyjne, często uniemożliwiają realizację własnej polityki rozwoju uczelni. Należy jednak mieć świadomość, że przepisy prawa z jednej strony powinny być na tyle sztywne i stabilne by zapewniać realizacje kształcenia na wysokim i porównywalnym poziomie oraz na tyle elastyczne by zostawiać swobodę działania uczelniom.

Wśród istotnych barier dla codzienne funkcjonowanie uczelni wyższych oraz realizacji polityki edukacyjnej wymieniano również:

- zbyt małe zaangażowanie społeczności studenckiej w życie uczelni i zbyt mała aktywność naukowa studentów oraz obojętność studentów względem procesu dydaktycznego, niezależnie od warunków i metod dydaktycznych;

- duży niedorozwój niektórych obszarów m.in. infrastruktury technicznej, wyposażenia, pomocy dydaktycznych;

- rozdrobnienie kierunków studiów;

- niedostateczne zaangażowanie pracowników naukowych w poszukiwaniu źródeł finansowania nauki;

- konkurencję na rynku usług edukacyjnych;

- niskie zarobki nauczycieli akademickich wymuszające poszukiwanie dodatkowych zajęć zarobkowych;

- mimo wszystko ograniczona samodzielność i niedostateczna autonomia uczelni.

Uczelnie jednoznacznie i „solidarnie” wskazują główne bariery i zagrożenia działalności oraz ich wielowątkowy charakter i synergiczne niekorzystne oddziaływanie na proces dydaktyczny. Wiele $\mathrm{z}$ nich uczelnia musi indywidualnie bez zewnętrznego wsparcia minimalizować bądź eliminować, w ramach polityki rozwoju, wykorzystując dostępne instrumenty lub poszukując nowych.

${ }^{25} \mathrm{~W}$. Mendys, Mienie i finanse szkót wyższych [w:] S. Waltoś, A. Rozmus, Szkolnictwo wyższe w Polsce. Ustrój-prawo-organizacja, Wydawnictwo WSIiZ w Rzeszowie, Rzeszów 2009, s.150. 


\section{Wyzwania dla polityki edukacyjnej szkół wyższych}

Zdecydowanie najważniejszym wyzwaniem dla szkół wyższych jest realizacja procesu dydaktycznego, w warunkach niżu demograficznego, który dotyka wszystkie uczelnie, nie tylko w regionie łódzkim. W tym kontekście niemal równorzędnym wyzwaniem jest uruchamianie nowych, atrakcyjnych kierunków kształcenia (tabela 9). Ze względu na specyfikę badanych uczelni, część opowiada się za uruchamianiem kierunków, przy współudziale podmiotów zewnętrznych. Charakterystyczne jest, że w tym pytaniu jedynie dwie uczelnie podkreśliły jako wyzwanie w zakresie kształcenia „konkurencję innych uczelni”. Rozkład udzielonych odpowiedzi pozwala jednak wnioskować, iż wszystkie one identyfikują wyzwania przez pryzmat budowania atrakcyjności ofert edukacyjnej i budowania pozycji konkurencyjnej w obszarze „kształcenie”. W tym kontekście warto podkreślić, iż dla trzech uczelni wyzwaniem jest nawiązywanie współpracy i rozwijanie kontaktów z uczelniami z zagranicy, co świadczy o otwartości oraz gotowości na umiędzynarodowienie kształcenia. Znamienne jest, iż ankietowane uczelnie, nie przywiązują wagi do nawiązywania współpracy i rozwijania kontaktów z uczelniami krajowymi. Sytuację taką można interpretować jako brak zaufania oraz rzeczywistą obawę o pozycję własnej uczelni. Przykłady z praktyki świadczą jednak o tym, że niektóre łódzkie uczelnie podejmują współpracę $\mathrm{w}$ zakresie kształcenia i przynosi ona zamierzone efekty (pozyskane środki finansowe, uruchomienie).

Tabela 9. Wyzwania dla szkół wyższych w zakresie procesu kształcenia

\begin{tabular}{|l|c|}
\hline \multicolumn{1}{|c|}{ Wyzwania } & Liczba wskazań \\
\hline niż demograficzny & $\mathbf{7}$ \\
\hline $\begin{array}{l}\text { uruchamianie kierunków kształcenia we współpracy z podmiotami gospodarczymi } \\
\text { /instytucjami }\end{array}$ & $\mathbf{4}$ \\
\hline niedobór środków na badania i rozwój & $\mathbf{4}$ \\
\hline uruchamianie nowych, innowacyjnych kierunków studiów & $\mathbf{3}$ \\
\hline nawiązywanie współpracy i rozwijanie kontaktów z uczelniami z zagranicy & $\mathbf{3}$ \\
\hline zwiększenie udziału „praktyków” w kształceniu studentów & $\mathbf{2}$ \\
\hline konkurencja szkół wyższych & $\mathbf{2}$ \\
\hline doskonalenie procesu kształcenia w systemie 2+3+4 & $\mathbf{0}$ \\
\hline nawiązywanie współpracy i rozwijanie kontaktów z uczelniami krajowymi & $\mathbf{0}$ \\
\hline
\end{tabular}

Źródło: opracowanie własne na podstawie badań ankietowych. 
Ciągłym wyzwaniem dla szkół wyższych oraz ważnym elementem ich polityki jest wdrażanie Krajowych Ram Kwalifikacji oraz sprostanie wymaganiom nowej ustawy o szkolnictwie wyższym, która weszła w życie 01.10.2012 r. Reforma odbierana i oceniana jest bardzo różnie przez środowisko akademickie. $\mathrm{W}$ zakresie zmian $\mathrm{w}$ systemie edukacji, w świetle przeprowadzonych badań, wskazywane są dwa skrajne stanowiska. W opinii respondentów, z jednej strony reforma prowadzi do indywidualizacji oferty kształcenia (5 wskazań) „oraz daje dużą autonomię i możliwość uruchamiania innowacyjnych kierunków kształcenia (4 wskazania). Wprowadzenie Krajowych Ram Kwalifikacji dla szkolnictwa wyższego, urealnia procesy kształcenia i uczenia się oraz pozwala na łatwiejszą współpracę z uczelniami zagranicznymi, w zakresie podwójnych i wspólnych dyplomów. W efekcie wprowadzane zmiany dają możliwość budowania pozycji konkurencyjnej uczelni i zwiększają szansę na jej rozwój w zakresie kształcenia.

$\mathrm{Z}$ drugiej strony reforma prowadzi do nadmiernej biurokratyzacji (4 wskazania), czy nawet wprowadza bałagan i dezorganizuje proces kształcenia ( 2 odpowiedzi). Implementowane nowe rozwiązania w zakresie organizacji, realizacji i walidacji programów kształcenia wymagają dużego zaangażowania pracowników naukowo-dydaktycznych, co niestety w części z nich wzbudza niechęć i niezadowolenie w kontekście koniecznych zmian.

W kontekście barier i wyzwań uczelnie wyraźnie artykułują cele polityki edukacyjnej na najbliższe lata. Jako priorytetowe wskazały cele w zakresie:

1. Doskonalenia jakości kształcenia poprzez m.in. udoskonalanie Krajowych Ram Kwalifikacji, uzyskanie akredytacji z wysokimi ocenami, wzmocnienie samodzielnej pracy studenta, wzmocnienie blend learningu, rozwój kadry naukowo-dydaktycznej;

2. Dywersyfikacji oferty edukacyjnej tj. poszerzania i różnicowania oferty dydaktycznej poprzez m.in. efektywny, z punktu widzenia potrzeb rynku pracy, dobór kierunków kształcenia (studia podyplomowe, kursy, staże, szkolenia etc.);

3. Inicjowania i rozwijania aktywności studenckiej;

4. Nawiązywania i intensyfikowania współpracy z otoczeniem;

5. Rozwoju infrastruktury i bazy akademickiej.

Szkoły wyższe regionu łódzkiego są świadomym uczestnikiem procesów społeczno-gospodarczych, bowiem modyfikują i kształtują swoją politykę edukacyjną pod kątem potrzeb i oczekiwań otoczenia. Wyraźnie eksponując przy tym kwestie jakości kształcenia oraz rozwijania aktywności i samodzielności studenckiej, co jest szczególnie istotne w kontekście budowania kapitału ludzkiego oraz społecznego.

Nowe modele akcentujące wątek gospodarczy funkcjonowania szkół wyższych i ich „służebną rolę” w gospodarce regionu czy kraju, nie podważają roli uczelni, jako instytucji edukacyjnej. Mimo ewolucji szkół wyższych, ich pier- 
wotna funkcja edukacyjna, niezależnie od uwarunkowań i obserwowanych trendów, nadal jest ważna, a w wielu przypadkach wiodąca. Współczesną misją szkolnictwa wyższego jest bowiem kreowanie wiedzy oraz jej rozpowszechnianie i wykorzystywanie dla dobra człowieka i społeczeństwa ${ }^{26}$.

Z perspektywy szkół wyższych regionu łódzkiego, instrumentami i działaniami, niezbędnymi dla realizacji polityki edukacyjnej $\mathrm{w}$ okresie dynamicznych przemian jest pomoc finansowa $\mathrm{z}$ zewnątrz na innowacje w edukacji (wyposażenie, pomoce i materiały dydaktyczne) oraz na rozwój kadry dydaktycznej (1) a równie ważne jest zwiększenie mobilności studentów i pracowników naukowych (2). Dla efektywnej działalności edukacyjnej niezbędne są przejrzyste przepisy prawne (3) oraz wsparcie instytucjonalno-organizacyjne uczelni (4). Zatem szkoły wyższe, ewidentnie chcą budować swój potencjał w obszarze edukacji, jej innowacyjności i otwartości, licząc na uregulowanie i stabilizację w zakresie ram prawnych i organizacyjnych. Poszukują również instrumentów umożliwiających skuteczną realizację obranej polityki rozwoju, pozwalających kompleksowo stymulować rozwój wszytkich obszarów aktywności uczelni.

Szkoły wyższe, niezależnie czy publiczne, czy niepubliczne, stają dziś w obliczu dynamicznych przemian przedsiębiorczego zarządzania tą instytucją. Faktem, który może świadczyć o potrzebie zmiany dotychczasowego funkcjonowania uczelni, która polegającej na odejściu od administrowania na rzecz planowania strategicznego, jest przygotowanie i realizacja strategii rozwoju.

Wszystkie uczelnie, uczestniczące $\mathrm{w}$ badaniu, mają opracowaną strategię rozwoju. W przypadku połowy badanych uczelni nie jest to pierwsze opracowanie. W przypadku 2 uczelni jest to opracowanie zupełnie nowe, bowiem zostało opracowane w 2013 r., 2 kolejne uczelnie przyjęły strategię odpowiednio w 2011 r. i 2012 r.

Staje się to zjawiskiem powszechnym, przy czym ważną kwestią jest na ile opracowana strategia jest, efektem oddolnej inicjatywy i wewnętrznej potrzeby, wyartykułowanych potrzeb i zamierzeń uczelni, a na ile mody i sytuacji wymuszonej. Ze względu na krótki okres realizacji trudno ocenić ich skuteczność. Dłuższy czas oraz efekty działalności, zweryfikują słuszność i skuteczność obranej drogi oraz pozwolą ocenić, na ile strategie były istotnym instrumentem polityki rozwoju uczelni. Z całą pewnością opracowywane dziś strategie rozwoju powinny minimalizować i ograniczać zidentyfikowane bariery rozwoju, jak również wychodzić naprzeciw wymagającym warunkom otoczenia, w jakich przyszło obecnie funkcjonować szkołom wyższym.

${ }^{26}$ Strategia rozwoju szkolnictwa wyższego: 2010-2020. Projekt środowiskowy, Warszawa, Wydawnictwo Uniwersytetu Warszawskiego, 2009, s. 63. http://www.krzasp.pl/files/ Strategia tom-1.pdf 


\section{Podsumowanie}

System edukacyjny jest systemem otwartym, a efekty jego funkcjonowania zależą od indywidualnych zasobów materialnych i niematerialnych, zdolności adaptacyjnych oraz otwarcia na zmiany. Dużym wyzwaniem dla szkół wyższych jest masowość szkolnictwa w warunkach niżu demograficznego, $\mathrm{z}$ jednoczesnym zapewnieniem wysokiej jakości kształcenia, na tle zróżnicowanego poziomu wiedzy absolwentów szkół ponadgimnazjalnych oraz dostosowania systemu kształcenia do zmieniających się potrzeb społecznych i gospodarczych.

Przeprowadzone badania pozwoliły określić stan i tendencje zmian na rynku usług edukacyjnych szkół wyższych regionu łódzkiego oraz spojrzeć z szerokiej perspektywy na aktywność uczelni, w zakresie polityki edukacyjnej i wskazać jej problemy, wyzwania i cele. Autonomia szkół wyższych, w zakresie programów kształcenia, pozwala uwolnić naturalną innowacyjność, w podejściu do planowania procesu dydaktycznego, począwszy od filozofii kierunku, przez program kształcenia, po stosowane metody dydaktyczne. Swoboda kreowania polityki edukacyjnej, pozwala wykorzystać potencjał uczelni jej pracowników i bazy materialnej. Przeprowadzone badania wyraźnie wskazują na wysoką aktywność wiodących uczelni regionu łódzkiego, w zakresie uruchamianych kierunków kształcenia i elastycznych form kształcenia oraz aplikowania o środki na doskonalenie procesu dydaktycznego. Niemniej jednak, należy mieć świadomość, co podkreślały ankietowane uczelnie, iż nadmierna liczba kierunków może prowadzić do asymetrii informacji między oferentem, a nabywcą usług edukacyjnych. Dodatkową barierą w interpretacji oferty kształcenia może być ,język efektów kształcenia", niezrozumiały dla absolwentów szkół ponadgimnazjalnych.

W warunkach realizacji strategii Europa 2020 i budowania inteligentnej specjalizacji regionów oraz zwiększenia mobilności kapitału ludzkiego wydaje się zasadne, by uczelnie o bogatej ofercie edukacyjnej, wyraźnie określiły wiodące obszary kształcenia i wyeksponowały specjalizację, w zakresie kierunków kształcenia. Dla identyfikacji uczelni przez potencjalnych studentów i podmioty gospodarcze, ale i kreowania wizerunku, korzystne jest wskazanie priorytetowych obszarów kształcenia. Powrót do uczelni monodycyplinarnych $\mathrm{w}$ obecnych warunkach nie jest możliwy, natomiast zbytnia transcyscyplinarność może być zagrożeniem. W tym kontekście, celowe jest podjęcie dyskusji na temat wiodących kierunków kształcenia, mających znacznie dla rozwoju gospodarki regionu łódzkiego.

Znamienne jest, iż rozmieszczenie szkół wyższych i ich jednostek w regionie łódzkim, jak i w Polsce, po raz kolejny zapewne ulegnie zmianie. Rozwój szkolnictwa wyższego $\mathrm{w}$ latach $90 \mathrm{XX}$ w. zaowocował lokalizacją uczelni w miastach, w których nie było tradycji akademickich (np. Kutno, Sieradz), 
wyjątkiem był m.in. Piotrków Trybunalski i Łowicz. W obecnej sytuacji małe subregionalne ośrodki akademickie traca znaczenie, gdyż nie są na tyle silne by konkurować z dużymi ośrodkami akademickimi. Pojawia się zatem pytanie, w jaki sposób zniwelować czy wyeliminować pojawiające się dysproporcje, w zakresie dostępności kształcenia oraz stymulować współpracę pomiędzy sferą nauki i gospodarki, również poza stolicą regionu.

Kolejną istotną kwestią jest współpraca pomiędzy szkołami wyższymi zarówno w zakresie kształcenia, jak i prowadzenia badań. Narastająca konkurencja pomiędzy uczelniami nie sprzyja nawiązaniu i określeniu obszarów współpracy. Przeprowadzone badania ankietowe wyraźnie wskazują, iż bardziej otwarte i skłonne do współpracy są uczelnie publiczne, które podejmują się realizacji wspólnych inicjatyw czy projektów.

Aktualna sytuacja szkół wyższych, ze względu na uwarunkowania zewnętrzne tj. umiędzynarodowienie procesu kształcenia, konkurencję i niekorzystną sytuację demograficzną w całej Europie oraz uwarunkowania wewnętrzne (niestabilność prawa, niedobory środków finansowych), wymusza kompleksowe podejście do określenia polityki rozwoju uczelni wyższej oraz reorientację spojrzenia na cele i zadania polityki edukacyjnej tj. projektowania oferty edukacyjnej i realizacji procesu dydaktycznego. Ważne jest, aby szkoły wyższe regionu łódzkiego, były rzeczywistym współuczestnikiem procesów rozwoju regionu, przy zachowaniu i poszanowaniu tradycji akademickich i posługi ogólnospołecznej.

\section{Bibliografia}

Benchmarking $w$ szkolnictwie wyższym. Wybrane problemy: elastyczność, e-learning, wewnętrzne systemy zapewniania jakości w systemie ksztatcenia, gospodarka zasobami dla poprawy produktywności i konkurencyjności- kontrola zarzqdcza, praca zbiorowa, J. Woźnicki, (red.), Fundacja Rektorów Polskich, Warszawa 2012, http://www.frp.org.pl/publikacje/FRPBench2012.pdf, (Dostęp: 30.08.2013).

Diagnoza stanu szkolnictwa wyższego w Polsce, Raport cząstkowy przygotowany przez konsorcjum Ernest\&Young Business Advisory oraz Instytut Badań nad Gospodarką Rynkowa, listopad 2012.

Diagnoza stanu szkolnictwa wyższego w Polsce, Raport cząstkowy przygotowany przez konsorcjum Ernest\&Young Business Advisory oraz Instytut Badań nad Gospodarką Rynkowa, listopad 2012.

Edukacja dla pracy. Raport o Rozwoju Społecznym Polska 2007, Program Narodów Zjednoczonych ds. Rozwoju, Warszawa 2007

Jurek P., E - learning w świetle badań nad uczeniem się. Czy komputer jest lepszy od nauczyciela? Meritum 1-2/ 2002. 
Mendys W., Mienie i finanse szkót wyższych [w:] Waltoś S., Rozmus A., Szkolnictwo wyższe w Polsce. Ustrój-prawo-organizacja, Wydawnictwo WSIiZ w Rzeszowie, Rzeszów 2009.

Nauka i technika 2011, Główny Urząd Statystyczny, Warszawa 2012.

Rzeńca A, System szkolnictwa wyższego w Polsce w obliczu wyzwań gospodarki opartej na wiedzy [w:] Z. Przygodzki, Regionalny wymiar polityki rozwoju kapitału ludzkiego. Przykład Włoch, Wielkiej Brytanii, Niemiec i Polski, Wydawnictwo Difin, Warszawa 2013.

Wissema J.G., Technostarterzy, dlaczego i jak? Warszawa 2005, http://www.parp.gov.pl/ files/ 74/81/105/ technostarterzy.pdf, (Dostęp: 10.10.2012r.).

Załączniki

Załącznik 1. Zamiejscowe ośrodki dydaktyczne w regionie łódzkim oraz szkół wyższych z regionu łódzkiego w Polsce w $2011 \mathrm{r}$.

\begin{tabular}{|c|c|c|}
\hline Szkoła wyższa & Miejscowość & Liczba studentów \\
\hline 1 & 2 & 3 \\
\hline \multirow{17}{*}{$\begin{array}{l}\text { Społeczna Akademia Nauk } \\
\text { w Łodzi }\end{array}$} & Świdnica & 153 \\
\hline & Bolesławiec & 141 \\
\hline & Olkusz & 77 \\
\hline & Zakopane* & 78 \\
\hline & Węgrów & 132 \\
\hline & Augustów & 129 \\
\hline & Skarżysko Kamienna & 176 \\
\hline & Koło & 151 \\
\hline & Szczecinek & 25 \\
\hline & Koszalin & 37 \\
\hline & Goleniów & 140 \\
\hline & Radomsko & 200 \\
\hline & Wieluń & 88 \\
\hline & Londyn & 212 \\
\hline & Bełchatów & 212 \\
\hline & Piotrków Trybunalski & 45 \\
\hline & Zduńska Wola & 297 \\
\hline \multirow{13}{*}{$\begin{array}{l}\text { Akademia Humanistyczno- } \\
\text {-Ekonomiczna w Łodzi }\end{array}$} & Głogów & 101 \\
\hline & Grudziądz & 161 \\
\hline & Bydgoszcz & 60 \\
\hline & Lublin & 23 \\
\hline & Warszawa & 51 \\
\hline & Jasło & 257 \\
\hline & Kartuzy & 115 \\
\hline & Wodzisław Śląski & 178 \\
\hline & Starachowice & 70 \\
\hline & Konin & 156 \\
\hline & Trzcianka & 161 \\
\hline & Kołobrzeg & 116 \\
\hline & Koszalin & 45 \\
\hline
\end{tabular}


54 Stan i kierunki zmian na rynku usług edukacyjnych...

Załącznik 1 (cd.)

\begin{tabular}{|l|l|c|}
\hline \multicolumn{1}{|c|}{1} & \multicolumn{1}{|c|}{ 2 } & \multicolumn{1}{|c|}{3} \\
\hline \multirow{5}{*}{} & Piotrków Trybunalski & 170 \\
\cline { 2 - 3 } & Radomsko & 62 \\
\cline { 2 - 3 } & Sieradz & 117 \\
\cline { 2 - 3 } & Wieluń & 172 \\
\cline { 2 - 3 } & Bełchatów & 29 \\
\hline \multirow{4}{*}{ Uniwersytet Łódzki } & Kutno & 93 \\
\cline { 2 - 3 } & Sieradz & 200 \\
\cline { 2 - 3 } & Tomaszów Mazowiecki & 32 \\
\cline { 2 - 3 } & Ostrołęka & 158 \\
\hline Politechnika Łódzka & Sieradzów & 64 \\
\cline { 2 - 3 } & Ostrów Wielkopolski & 260 \\
\hline Politechnika Radomska & Tomaszów Mazowiecki & 120 \\
\hline \multirow{2}{*}{$\begin{array}{l}\text { Szkoła Główna Gospodarstwa Wiej- } \\
\text { skiego w Warszawie }\end{array}$} & Widzew & 109 \\
\cline { 2 - 3 } $\begin{array}{l}\text { Wyższa Szkoła Menedżerska } \\
\text { w Warszawie }\end{array}$ & Lowicz & 29 \\
\hline
\end{tabular}

*AHE w Kozienicach i Błoniach, Jarosławcu, Człuchowie, Słupsku, Bytomiu, Lidzbarku Warmińskim kończy swoja działalność.

Wyróżniono zamiejscowe ośrodki dydaktyczne zlokalizowane w województwie łódzkim.

Źródło: Szkoły i ich finanse w 2011r., Główny Urząd Statystyczny, Warszawa 2012.

Załącznik 2. Filie, zamiejscowe podstawowe jednostki organizacyjne w regionie łódzkim oraz szkół wyższych z regionu łódzkiego w Polsce w 2011 r.

\begin{tabular}{|l|l|c|}
\hline \multicolumn{1}{|c|}{ Szkoła Wyższa } & \multicolumn{1}{|c|}{ Miejscowość } & Liczba studentów \\
\hline \multicolumn{1}{|c|}{$\begin{array}{c}\text { Społeczna Akademia Nauk } \\
\text { w Lodzi }\end{array}$} & \multicolumn{1}{|c|}{2} & 3 \\
\cline { 2 - 3 } & Zrodnica & 249 \\
\cline { 2 - 3 } & Zduńska Wola & 23 \\
\cline { 2 - 3 } & Garszawa & 3889 \\
\cline { 2 - 3 } & Garwolin & 232 \\
\cline { 2 - 3 } & Słupsk & 74 \\
\cline { 2 - 3 } & Skarżysko-Kamienna & 15 \\
\cline { 2 - 3 } & Ostrowiec Świętokrzyski & 1066 \\
\cline { 2 - 3 } & Kołobrzeg & 420 \\
\hline \multirow{5}{*}{ Ści w Łodzza Szkoła Informatyki i Umiejętno- } & Bydgoszcz & 595 \\
\cline { 2 - 3 } & Włocławek & 115 \\
\cline { 2 - 3 } & Opatówek & 343 \\
\hline Uniwersytet Łódzki** & Tomaszów Mazowiecki & 912 \\
\hline \multirow{4}{*}{ Wyższa Szkoła Kupiecka w Łodzi } & Piotrków Trybunalski & 63 \\
\cline { 2 - 3 } & Sieradz & 55 \\
\cline { 2 - 3 } & Konin & 76 \\
\cline { 2 - 3 } & Szczecinek & 95 \\
\hline
\end{tabular}


Załącznik 2 (cd.)

\begin{tabular}{|l|l|c|}
\hline \multicolumn{1}{|c|}{1} & \multicolumn{1}{|c|}{2} & 3 \\
\hline $\begin{array}{l}\text { Uniwersytet Humanistyczno- } \\
\text { Przyrodniczy im. J. Kochanowskiego } \\
\text { w Kielcach** }\end{array}$ & Piotrków Trybunalski & 3316 \\
\hline $\begin{array}{l}\text { Papieski Wydział Teologiczny im. Św. } \\
\text { Jana Chrzciciela w Warszawie** }\end{array}$ & Lowicz & 29 \\
\hline $\begin{array}{l}\text { Wyższa Szkoła Zarządzania i Prawa } \\
\text { im. H. Chodkowskiej w Warszawie }\end{array}$ & Lódź & 29 \\
\hline $\begin{array}{l}\text { Wschód-Zachód Szkoła Wyższa } \\
\text { im. H. Jóźwiaka w Łodzi }\end{array}$ & Nowy Sącz & 80 \\
\hline $\begin{array}{l}\text { Wyższa Szkoła Turystyki i Hotelarstwa } \\
\text { w Łodzi }\end{array}$ & Gostynin & 44 \\
\hline $\begin{array}{l}\text { Akademia Humanistyczno- } \\
\text { Ekonomiczna w Łodzi }\end{array}$ & Wodzisław Śląski & 331 \\
\hline $\begin{array}{l}\text { Wyższa Szkoła Finansów i Informatyki } \\
\text { im. Prof. J. Chechlińskiego w Łodzi* }\end{array}$ & Kalisz & 246 \\
\hline
\end{tabular}

\footnotetext{
*w Starachowicach tylko absolwenci; ** filie Wyróżniono filie i zamiejscowe podstawowe jednostki organizacyjne zlokalizowane w województwie łódzkim.
}

Źródło: Szkoły i ich finanse w 2011r., Główny Urząd Statystyczny, Warszawa 2012. 